\title{
ANALISIS PERBANDINGAN PEGAWAI TETAP DAN PEGAWAI OUTSOURCING BAGIAN KEBERSIHAN DITINJAU DARI PEMBERDAYAAN, KEPUASAN KERJA DAN KOMITMEN ORGANISASI
}

\author{
Cucu Hodijah \\ Program Ilmu Komunikasi Institut Manajemen Wiyata Indonesia Sukabumi Jawa Barat, \\ Indonesia \\ cucu_hodijah@imwi.ac.id \\ Rika Solihah \\ Akademi Pariwisata NHI, Bandung Jawa Barat, Indonesia \\ rikasolihahnulhakim@gmail.com
}

\begin{abstract}
This study aims to analyze the Comparison of Permanent Employees with Employees Outsourcing the Cleanliness Section viewed from Empowerment, Job Satisfaction and Organizational Commitment. The research hypothesis is that there are differences between Permanent and Outsourcing Employees seen from Empowerment, Job Satisfaction and Organizational Commitment. Research is a quantitative study using a comparative / difference approach. Data collected using a questionnaire with a Likert scale. Data processing using one way ANOVA and Independent Sample t-test and descriptive analysis data using the average technique. The results showed that there were differences in terms of Empowerment, Job Satisfaction and Organizational Commitment between Permanent Employees and Outsourcing Employees, where the Permanent Employee Organizational Commitment variable had a higher value than the Outsourcing Officer.
\end{abstract}

Keywords: Permanent Employees, Employee Outsourcing, Empowerment, Job Satisfaction, Organizational Commitment.

\section{PENDAHULUAN}

Pada era globalisasi, perkembangan ilmu pengetahuan dan teknologi yang semakin pesat yang secara otomatis berpengaruh pada perubahan dalam segala aspek kehidupan organisasi, baik itu perubahan di bidang ekonomi, politik, sosial dan budaya di setiap negara. Hal tersebut berdampak pada betapa penting dan mendesaknya peranan sumberdaya manusia yang memiliki kualitas, kompetensi dan kinerja yang tinggi untuk menghadapi perubahanperubahan dalam berbagai dimensi tersebut. Selain itu di era globalisasi tersebut persaingan semakin ketat menuntut peran serta sumberdaya manusia yang memiliki kemampuan professional dibidangnya. Sumber daya manusia merupakan sumber daya terpenting dalam satu organisasi dimana orang-orang atau karyawan tersebut memberikan tenaga, kreativitas dan usaha mereka kepada organisasi. Oleh karena itu manusia merupakan salah satu faktor penentu keberhasilan dalam suatu organisasi karena manusia memberikan kontribusi terbesar dibandingkan dengan faktor-faktor lain. Karena manusia merupakan salah satu faktor penentu keberhasilan suatu organisasi baik itu organisasi besar maupun kecil, yang memiliki visi untuk kepentingan manusia dan dalam 
pelaksanaan misinya dikelola oleh manusia itu sendiri, sehingga manusia menjadi faktor strategis.

Untuk mendapatkan tenaga kerja atau karyawan yang memiliki kemampuan yang sesuai dengan yang dibutuhkan oleh perusahaan maka bagian sumber daya manusia dalam suatu perusahaan harus mengadakan penarikan tenaga kerja atau karyawan secara selektif agar sesuai dengan job description dan job specification, pimpinan perusahaan juga harus dapat membina, mengkoordinasikan dan mengarahkan karyawan sesuai dengan tujuan perusahaan.Hal ini sangat diperlukan karena tidak semua karyawan baru secara langsung dapat sesuai dengan kebutuhan. Mereka harus dilatih agar, dapat mengerjakan pekerjaannya dengan efektif.

Perkembangan sumber daya manusia pada perusahaan atau instansi akan menghasilkan karyawan yang terampil dan dapat menyelesaikan tugas dengan baik. Untuk mendapatkan karyawan yang terampil sangat diperlukan peningkatan pengetahuan dan keterampilan melalui pendidikan dan pelatihan, yang dilaksanakan secara teratur dan terarah. Dengan adanya program pelatihan keterampilan dan pengetahuan karyawan sesuai dengan perkembangan ilmu pengetahuan dan teknologi, oleh sebab itu pendidikan dan pelatihan dipandang sangat perlu bagi setiap karyawan untuk menjadi bekal dalam melaksanakan tugas seharihari, Universitas Widyatama merupakan salah satu institusi yang tugas dan fungsinya sebagai penyedia kebutuhan Pendidikan dan kepentingan masyarakat dengan memiliki visi "Menjadi Universitas Unggul Dan Mandiri di Indonesia Untuk Menghasilkan Tenaga Professional Yang
Memenuhi Kebutuhan Industri Dan Masyarakat Serta Mampu Bersaing Dalam Lingkungan Global Tahun 2028.”

Untuk menunjang visi tersebut perlu didukung oleh misi yang pelaksanaannya dilakukan oleh seluruh pegawai dan dosen yang ada di Universitas Widyatama. Adapun misi Universitas Widyatama adalah Value Creation yang diuraikan sebagai berikut:

1. Menyelenggarakan program pendidikan, penelitian dan pengabdian kepada masyarakat yang menunjang pengembangan dan penerapan ilmu pengetahuan, teknologi dan seni.

2. Menciptakan lingkungan yang kondusif bagi pelaksanaan kegiatan belajar mengajar serta penelititan yang efisien dan efektif sehingga dapat menghasilkan lulusan yang kreatif dan inovatif.

3. Mengupayakan keterkaitan dan relevansi seluruh kegiatan akademis dalam rangka pembentukan manusia yang berbudi luhur.

4. Melakukan kerjasama dengan berbagai pihak, baik di dalam maupun di luar negeri agar proses pembelajaran selalu mutakhir.

Sumber daya manusia Universitas Widyatama terdiri dari Dosen, pegawai bagian administrasi, pegawai lapangan, pegawai bagian kebersihan dan Satpam.Semua unsur tersebut merupakan bagian yang tak terpisahkan dalam mencapai visi dan misi institusi.

Saat ini Universitas Widyatama merupakan Universitas yang sangat konsen terhadap kebersihan baik itu kebersihan ruang kerja, ruang kelas maupun lingkungan sekitar universitas, hal ini terbukti dari para pimpinan yang terjun langsung mengawasi kebersihan, terutama dari pimpinan Yayasan Widyatama. 
Mulai tahun 2008, pegawai kebersihan Universitas Widyatama terbagi menjadi 2 bagian yaitu pegawai kebersihan yang bersifat tetap (organik) dan pegawai kebersihan outsourcing, hal ini dilakukan oleh manajemen Yayasan Widyatama memungkinkan untuk berperan lebih proaktif dan strategis berfokus pada kompetensi utama mereka dalam meningkatkan efisiensi.

Berikut tabel jumlah pegawai kebersihan Universitas Widyatama pada tahun 2018:

Tabel 1

Data Pegawai Kebesihan Universitas WidyatamaTahun 2018

\begin{tabular}{ccc}
\hline No. & $\begin{array}{c}\text { Pegawai } \\
\text { kebersihan tetap } \\
\text { (organic) }\end{array}$ & $\begin{array}{c}\text { Pegawai } \\
\text { kebersihan } \\
\text { Outsourcing }\end{array}$ \\
\hline 1 & $\mathbf{3 0}$ & $\mathbf{3 5}$ \\
\hline
\end{tabular}

Pegawai bagian kebersihan ini harus membersihkan bagian-bagian yang terlihat dalam tabel 2 dibawah ini:

\section{Tabel 2}

Ruangan yang dimiliki oleh Universitas Widyatama Tahun 2018

\begin{tabular}{clc}
\hline No. & \multicolumn{1}{c}{ Uraian } & $\begin{array}{c}\text { Jumlah } \\
\text { Ruangan/Luas }\end{array}$ \\
\hline 1. & Ruang kuliah & 77 ruangan \\
\hline 2. & Laboratorium & 26 ruangan \\
\hline 3. & Perpustakaan & 18 ruangan \\
\hline 4. & Ruang studio & 7 ruangan \\
\hline 5. & Kegiatan & 32 ruangan \\
& Mahasiswa & \\
\hline 6. & Ruang dosen & 41 ruangan \\
\hline 7. & Pusat studi & 4 ruangan \\
\hline 8 & Ruang serba guna & 3 ruangan \\
\hline 9. & Ruang olahraga & 1 ruangan \\
\hline 10. & Ruang penelitian & 5 ruangan \\
\hline 11. & Ruang pengabdian & 1 ruangan \\
& Masyarakat & \\
\hline 12. & Ruang percetakan & 4 ruangan \\
\hline 13. & Koperasi & 3 ruangan \\
& mahasiswa & \\
\hline 14. & Bursa mahasiswa & 1 ruangan \\
\hline 15. & poliklinik & 2 ruangan \\
\hline 16. & Sarana ibadah & 7 ruangan \\
\hline 17. & kantin & 4 ruangan \\
\hline
\end{tabular}

\begin{tabular}{llc}
\hline No. & \multicolumn{1}{c}{ Uraian } & $\begin{array}{c}\text { Jumlah } \\
\text { Ruangan/Luas }\end{array}$ \\
\hline 18. & Toilet & 89 ruangan \\
\hline 19. & $\begin{array}{l}\text { Ruang pejabat } \\
\text { struktural }\end{array}$ & 21 ruangan \\
\hline 20. & Ruangan karyawan & 26 ruangan \\
\hline 21. & Ruang rapat & 7 ruangan \\
\hline 22. & Gudang & 27 ruangan \\
\hline 23. & Dapur & 10 ruangan \\
\hline 24. & Lobby & 5 ruangan \\
\hline 25. & Elektical & 14 ruangan \\
\hline 26. & Koridor & \\
\hline 27. & Parkir & \\
\hline 28 & taman & 438 ruangan \\
\hline & Jumlah
\end{tabular}

Dari tabel 1 dan tabel 2 diatas dapat dilihat bahwa pegawai kebersihan Universitas Widyatama memiliki beban kerja yang cukup berat, dikarenakan harus membersihkan sebanyak 438 ruangan dan $28.000 \mathrm{~m} 2$ taman dengan jumlah pegawai bagian kebersihan yang terbatas.

Untuk mencapai kinerja sumber daya manusia yang lebih baik, manajemen Yayasan Widyatama harus memberikan perhatian yang lebih terhadap para pegawainya.Yayasan tidak bisa hanya fokus pada tenaga kerja outsourcing guna meningkatkan efektifitas institusi.Namun Yayasan harus memperhatikan pegawai tetap yang juga memiliki peranan penting dalam kemajuan institusi.Maka dari itu diperlukan adanya keseimbangan antara pegawai tetap dan pegawai outsourcing yang ada di yayasan terutama dalam hal pemberdayaan, kepuasan kerja, dan komitmen organisasional pegawai yang terlihat dari aktivitas-aktivitas dalam melaksanakan tugas dan tanggungjawabnya.

Pemberdayaan adalah pemberian tanggungjawab dan wewenang dari manajer kepada karyawan, yang melibatkan adanya sharing informasi dan pengetahuan untuk memandu karyawan dalam bertindak sesuai dengan tujuan organisasi (Rue, 2016). Pemberdayaan dapat mempengaruhi pengembangan kebijakan dan proses kepegawaian melalui kontrol lingkungan kerja. 
Kepuasan kerja dikatakan sebagai nilai penting dalam perusahaan karena dalam peningkatan kepuasan kerja pegawai maka akan meningkatkan kinerja dan produktivitas perusahaan, karena menurut (Zainal, Ramly, Mutis, \& Arafah, 2019) kepuasan merupakan evaluasi yang menggambarkan seseorang atas perasaan sikapnya senang atau tidak senang, puas atau tidak puas dalam bekerja. Kemudian pegawai yang memiliki komitmen organisasional yang tinggi akan bersedia memberikan kontribusi yang lebih besar daripada yang diharapkan dalam rangka mewujudkan tujuan perusahaan.

Perkembangan kemajuan teknologi maupun informasi yang pesat dewasa ini semakin menuntut kemampuan, kecepatan dan ketepatan manusia dalam mengerjakan sesuatu. Perkembangan kemajuan tersebut tidak hanya membawa dampak kepada manusia sebagai individu tetapi juga kepada organisasi yang mempunyai badan, maksud dan tujuan.

Oleh karena itu peningkatan kualitas sumber daya manusia melalui pemberdayaan pegawai sangat diperlukan, hal ini untuk mengubah perilaku agar lebih mampu melaksanakan aktifitas disegala bidang. Pada dasarnya pengembangan sumber daya manusia adalah peningkatan kinerja pegawai yang mencerminkan kemampuan anggota organisasi dalam bekerja.

Demikian juga halnya dengan pegawai kebersihan Yayasan Widyatama baik itu pegawai tetap maupun pegawai outsoucing harus diberdayakan guna meningkatkan kinerja pegawai serta mengoptimalkan kepuasan pegawai kebersihan sehingga dapat menciptakan komitmen pada perusahan.

Berdasarkan fenomena diatas, penulis tertarik untuk mengetahui bagaimana "Analisis Perbandingan Pegawai Tetap Dan Pegawai Outsourcing Bagian Kebersihan Ditinjau Dari Pemberdayaan, Kepuasan Kerja Dan Komitmen Organisasi (Studi Kasus Universitas Widyatama Bandung)".

\section{TINJAUAN PUSTAKA}

\section{A. Pegawai Tetap}

Berdasarkan Peraturan Dirjen Pajak nomor 31/PJ/2009, Pegawai tetap adalah pegawai yang menerima atau memperoleh penghasilan dalam jumlah tertentu secara teratur. termasuk anggota dewan komisaris dan anggota dewan pengawas yang secara teratur terus menerus ikut mengelola kegiatan perusahaan secara langsung, serta pegawai yang bekerja berdasarkan kontrak untuk suatu jangka waktu tertentu sepanjang pegawai yang bersangkutan bekerja penuh (fulltime) dalam pekerjaan tersebut.

Sedangkan pengertian pegawai tetap menurut (Faisal, 2009) pegawai tetap adalah pegawai yang menerima atau memperoleh imbalan dalam jumlah tertentu secara teratur (berkala). Termasuk kedalam pegawai tetap adalah pegawai swasta, pegawai negeri dan penerima pensiun. Imbalan pegawai tetap bisa berupa gaji, beragam tunjangan, penghasilan tidak teratur seperti bonus, honorarium jasa produksi, gratifikasi dan lain sebagainya.

\section{B. Pegawai Outsourcing}

Menurut (Gary, 2009) outsourcing berarti menyuruh vendor dari luar untuk menyuplai layanan (seperti manajemen tunjangan, riset pasar, atau menufaktur) yang sebelumnya dilakukan karyawan perusahan sendiri di dalam perusahaaan.

Dalam hukum ketenagakerjaan di Indonesia pegawai outsourcing ini diatur dalam Undang-Undang Republik Indonesia.Nomor 13 Tahun 
2003. Tentang.Ketenagakerjaan Pasal 64 menyatakan Perusahaan dapat menyerahkan sebagian pelaksanaan pekerjaan kepada perusahaan lainnya melalui perjanjian pemborongan pekerjaan atau penyediaan jasa pekerja/buruh yang dibuat secara tertulis.

Menurut (Herawati, 2010) Outsourcing adalah bentuk hubungan kerja yang termasuk dalam kategori Precarious Work, istilah yang biasa dipakai secara internasional untuk menunjukkan situasi hubungan kerja yang tidak tetap, waktu tertentu, kerja lepas,tidak terjamin/ tidak aman dan tidak pasti.

Dari pengertian diatas dapat disimpulkan bahwa outsourcing adalah hubungan kontrak kerja untuk menyediakan layanan bisnis yang disedikan oleh pihak ekternal berdasarkan penjanjian antara pihak internal dan ekternal.

\section{Pemberdayaan}

Setiap perusahaan tentu saja menginginkan semua pegawainya memiliki keterlibatan atau pemberdayaan dalam organisasi guna menghadapi persaingan yang semakin ketat dalam dunia bisnis. Gibson et.al.dalam (Leovani, 2016) menyebutkan bahwa pemberdayaan adalah pemberian kesempatan dan dorongan kepada para karyawan untuk mendayagunakan bakat, ketrampilanketrampilan, sumberdaya-sumberdaya, dan pengalaman-pengalaman mereka untuk menyelesaikan pekerjaan secara tepat waktu. Hasil-hasil yang dicapai dalam menerapkan konsep pemberdayaan di berbagai perusahaan adalah peningkatan efisiensi dan kualitas dalam produksi dan pelayanan.

Conger dan Kanungo dalam (Fadzilah, 2006) mendefinisikan pemberdayaan sebagai konsep motivasional dari self-efficacy. Pemberdayaan menurut mereka merupakan proses untuk meningkatkan perasaan self-efficacy diantara anggota-anggota organisasi melalui identifikasi yang mendorong ketidakberdayaan dan menyingkirkan hal-hal tersebut melalui praktek organisasi formal dan teknik-teknik informal dengan menyediakan informasi.

Menurut Nangoi

(2015:31) pemberdayaan menekankan pada:

1. Pemberian tanggung jawab, wewenang dan power pada karyawan

2. Peningkatan partisipasi dan keterlibatan karyawan dalam organisasi

3. Partisipasi dan keterlibatan karyawan dalam pengambilan keputusan jelas mengandung nilai demokrasi

4. Pendekatan bottom-up dan partisipatif, karyawan mendapatkan perlakukan manusiawi untuk melakukan kemampuan berpikir daripada melakukan pekerjaan seperti mesin.

\section{Kepuasan Kerja}

Kepuasan kerja dalam perusahaan merupakan salah satu elemen yang sangat penting, karena kepuasan kerja akan mempengaruhi perilaku pekerjanya seperti malas, rajin, inisiatif, inovatif dan sebagainya. Kepuasan kerja menurut Zenal (2014:620) merupakan evaluasi 
yang menggambarkan seseorang atas perasaan sikapnya senang atau tidak senang, puas atau tidak puas dalam bekerja.

Menurut kreitner (2014:169) kepuasan kerja adalah sebuah tanggapan afektif atau emiosional terhadap berbagai segi pekerjaan seseorang.

Dalam dunia kerja kepuasan itu salah satunya bisa mengacu kepada kompensasi yang diberikan oleh perusahaan, termasuk gaji atau imbalan dan fasilitas kerja lainnya seperti rumah dinas dan kendaraan kerja.

Edward Lawler dalam Zanel (2014:622) menjelaskan salah satu model teori yang berkaitan dengan kepuasan kerja, yaitu yang dikenal dengan teori kesetaraan: intinya teori ini menjelaskan kepuasan dan ketidakpuasan dengan pembayaran. Perbedaan antara jumlah yang diterima dengan jumlah yang dipersepsikan oleh karyawan lain merupakan penyebab utama terjadinya ketidakpuasan. Untuk itu pada dasarnya ada tiga tingkatan karyawan yaitu:

1. Memenuhi kebutuhan dasar karyawan

2. Memenuhi harapan karyawan sedemikian rupa, sehingga mungkin tidak mau pindah kerja ke tempat lain

3. Memenuhi keinginan karyawan dengan mendapat lebih dari apa yang diharapkan.

\section{E. Komitmen Organisasi}

Menurut Fatimah dalam (Devi, Noer, \& Rahmawati, 2017) Komitmen organisasional merupakan ikatan individu dengan organisasi. Pegawai yang memiliki komitmen tinggi terhadap pekerjaanya menunjukkan keinginan yang lebih tinggi untuk terlibat dalam kegiatan organisasional yang baik untuk mempertahankan status pekerjaan mereka. Mereka cenderung lebih puas dengan situasi pekerjaan mereka daripada pegawai lainnya. Komitmen Organisasional juga mempengaruhi peningkatan modal intelektual dan kinerja keuangan perusahaan.

Menurut Robbins dalam

(Nurandini \& Lataruva, 2014)

Komitmen organisasional adalah suatu keadaan dimana seorang karyawan memihak organisasi tertentu serta tujuan-tujuan dan keinginannya untuk mempertahankan keanggotaan dalam organisasi tersebut. Jadi keterlibatanpekerjaan yang tinggi berarti memihak pada pekerjaan tertentu seorang individu, sementara komitmen organisasional yang tinggi berarti memihak organisasi yangmerekrut individu tersebut.

Menurut Robbins dalam

(Nurandini \& Lataruva, 2014) menyatakan bahwa terdapat 3 macamdimensi komitmen organisasio nal yaitu : Komitmen Afektif, Komitmen, Normatif, dan Komitmen Berkelanjutan.Komitmen Afektif yaitu Perasaanemosional untuk organisasi dankeyakinan dalam nilai-nilainya. Komitmen Normatif yaitu perasaan wajib untuk tetap berada dalam organisasi karena memang harus begitu, tindakan tersebut merupakan hal benar yang harus dilakukan. Komi tmen berkelanjutan yaitu nilai ekonomi yangdirasa dari bertahan 
dalam suatu organisasi bila dibandingkan dengan meninggalkan organisasi tersebut.

\section{F. Kerangka Pemikiran}

Sumber daya manusia merupakan sumber daya terpenting dalam satu organisasi dimana orangorang atau karyawan tersebut memberikan tenaga, kreativitas dan usaha mereka kepada organisasi. Oleh karena itu manusia merupakan salah satu faktor penentu keberhasilan dalam suatu organisasi karena manusia memberikan kontribusi terbesar dibandingkan dengan faktorfaktor lain.

Begitu juga halnya dengan Universitas Widyatama, dimana sumber daya manusia merupakan aset yang sangat berharga dibandingkan dengan faktor lainnya, tidak terkecuali sumberdaya manusia yang bekerja dibagian kebersihan, yang saat ini terdiri dari dua macam status yaitu pegawai kebersihan tetap dan pegawai kebersihan outsourching.

Baik itu pegawai tetap maupun pegawai outsoucing harus diberdayakan guna meningkatkan kinerja pegawai serta mengoptimalkan kepuasan pegawai kebersihan sehingga dapat menciptakan komitmen pada perusahan.

Gibson et.al. dalam (Leovani, 2016) menyebutkan bahwa pemberdayaan adalah pemberian kesempatan dan dorongan kepada para karyawan untuk mendayagunakan bakat, ketrampilan-ketrampilan, sumberdaya-sumber daya, dan pengalaman-pengalaman mereka untuk menyelesaikan pekerjaan secara tepat waktu. Hasil-hasil yang dicapai dalam menerapkan konsep pemberdayaan di berbagai perusahaan adalah peningkatan efisiensi dan kualitas dalam produksi dan pelayanan.

Sedangkan kepuasan kerja menurut Zenal (2014:620) merupakan evaluasi yang menggambarkan seseorang atas perasaan sikapnya senang atau tidak senang, puas atau tidak puas dalam bekerja.

Menurut Fatimah dalam (Devi et al., 2017) Komitmen organisasional merupakan ikatan individu dengan organisasi. Pegawai yang memiliki komitmen tinggi terhadap pekerjaanya menunjukkan keinginan yang lebih tinggi untuk terlibat dalam kegiatan organisasional yang baik untuk mempertahankan status pekerjaan mereka. Mereka cenderung lebih puas dengan situasi pekerjaan mereka daripada pegawai lainnya. Komitmen Organisasional juga mempengaruhi peningkatan modal intelektual dan kinerja keuangan perusahaan.

Untuk memperjelas variabelvariabel membandingkan pemberdayaan, kepuasan kerja dan komitmen organisasi, maka kerangka pemikiran teoritis yang dibuat oleh penulis adalah sebagai berikut:

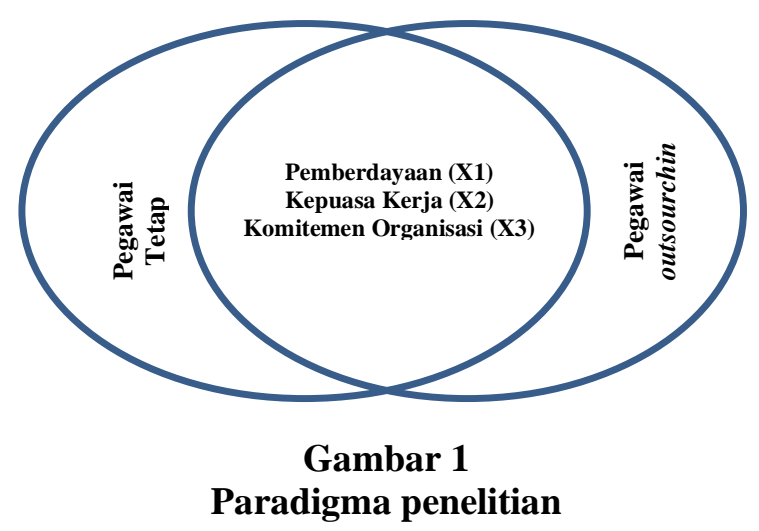


Berdasarkan tujuan penelitian dan rumusan kerangka pemikiran, maka penulis merumuskan hipotesis penelitian menjadi 3 hipotesis sebagai berikut:

1. Terdapat perbedaan pemberdayaan antara pegawai tetap dengan pegawai outsourcing.

2. Terdapat perbedaan kepuasan kerja antara pegawai tetap dengan pegawai outsourcing.

3. Terdapat perbedaan komitmen organisasional antara pegawai tetap dengan pegawai outsourcing.

\section{METODE PENELITIAN}

\section{A. Jenis Penelitian}

Dalam melakukan penelitian penulis memilih untuk melakukan penelitian kuantitatif, dengan melakukan pendekatan komparatif. Adapun jenis data yang digunakan adalah data primer dengan langsung memperolehnya dari responden melalui kuesioner.

\section{B. Populasi dan Sampel}

Di dalam penelitian ini yang menjadi populasinya adalah seluruh pegawai bagian kebersihan baik berstatus tetap maupun outsourcing di Universitas Widyatama. Sedangkan sampel yang diambil dalam penelitian ini adalah seluruh pegawai tetap bagian kebersihan yang berjumlah 30 orang dan pegawai outsourching bagian kebersihan sebanyak 35 orang.

\section{Teknik Pengumpulan Data}

Alat yang digunakan untuk mengumpulkan data primer dalam penelitian ini adalah kuesioner. Skala yang digunakan dalam penelitian ini adalah skala likert, skala ini berinterasi 1-5 serta dengan pilihan jawaban.

\section{Metode Analisis}

Metode analisis data merupakan salah satu cara yang digunakan setelah data dari seluruh responden atau sumber data lain terkumpul. Kegiatan dalam analisis data adalah mengelompokkan data berdasarkan variabel dari jenis responden, mentabulasi data berdasarkan variabel dari seluruh responden, menyajikan data tiap variabel yang diteliti, melakukan perhitungan untuk menjawab rumusan masalah, dan melakukan perhitungan untuk menguji hipotesis yang telah diajukan (Sugiyono, 2012).

Dalam penelitian ini metode analisis yang digunakan adalah analisis Uji instrument (uji validitas dan uji reliabilitas), uji asumsi klasik, dan uji independent sample t-test.

Validitas adalah suatu ukuran yang menunjukkan tingkat kevalidan atau kehsahihan suatu instrument.

Suatu Instrumen yang valid mempunyai validitas tinggi dan sebaliknya, bila tingkat validitasnya rendah maka instrument tersebut kurang valid (Syahrani, 2008). Oleh karena itu, penulis menguji tingkat validitas kuesioner yang disebarkan kepada para responden.

Reliabilitas menunjuk pada suatu pengertian bahwa sesuatu instrument dapat dipercaya untuk digunakan sebagai alat pengumpul data karena instrument tersebut sudah dianggap baik. Reliabel artinya dapat dipercaya juga dapat diandalkan, sehingga beberapa kali diulang pun hasilnya akan tetap sama (konsisten) (Syahrani, 2008). 


\section{HASIL PENELITIAN DAN} PEMBAHASAN

\section{A. Karakteristik Responden}

Gambaran tentang karakteristik responden diperoleh dari data diri yang terdapat pada bagian data identitas responden yang meliputi: jenis kelamin, usia, pendidikan terakhir, masa kerja, dan status karyawan. Untuk memperjelas karakteristik responden yang dimaksud, maka akan disajikan tabel mengenai data responden seperti yang dijelaskan berikut ini:

Tabel 3

Karakteristik Responden Berdasarkan Jenis Kelamin

\begin{tabular}{lcccc}
\hline \multirow{2}{*}{$\begin{array}{c}\text { Jenis } \\
\text { Kelamin }\end{array}$} & \multicolumn{2}{c}{$\begin{array}{c}\text { Pegawai } \\
\text { Tetap }\end{array}$} & \multicolumn{2}{c}{$\begin{array}{c}\text { Pegawai } \\
\text { Outsourcing }\end{array}$} \\
\cline { 2 - 5 } & $\mathbf{J m l}$ & $\mathbf{( \% )}$ & $\mathbf{J m l}$ & $\mathbf{( \% )}$ \\
\hline Laki-laki & 30 & $100 \%$ & 28 & $80 \%$ \\
\hline Perempuan & 0 & $0 \%$ & 7 & $20 \%$ \\
\hline Total & 30 & $100 \%$ & 35 & $100 \%$ \\
\hline
\end{tabular}

Dari tabel 3 diatas berdasarkan karakteristis jenis kelamin diketahui bahwa semua pegawai tetap kebersihan adalah laki-laki, sedangkan untuk pegawai outsourcing $80 \%$ berjenis kelamin laki-laki.

Tabel 4

Karakteristik Responden Berdasarkan Usia

\begin{tabular}{ccccc}
\hline \multirow{2}{*}{ Usia } & \multicolumn{2}{c}{ Pegawai Tetap } & \multicolumn{2}{c}{$\begin{array}{c}\text { Pegawai } \\
\text { Outsourcing }\end{array}$} \\
\cline { 2 - 5 } & $\mathbf{J m l}$ & $\mathbf{( \% )}$ & $\mathbf{J m l}$ & $\mathbf{( \% )}$ \\
\hline $20-25$ & 0 & $0 \%$ & 13 & $37 \%$ \\
\hline $25-30$ & 0 & $0 \%$ & 9 & $26 \%$ \\
\hline $31-35$ & 1 & $3 \%$ & 6 & $17 \%$ \\
\hline $36-40$ & 5 & $17 \%$ & 6 & $17 \%$ \\
\hline $41-45$ & 6 & $20 \%$ & 1 & $3 \%$ \\
\hline $46-50$ & 11 & $37 \%$ & 0 & $0 \%$ \\
\hline $51-55$ & 6 & $20 \%$ & 0 & $0 \%$ \\
\hline $56-60$ & 1 & $3 \%$ & 0 & $0 \%$ \\
\hline Total & $\mathbf{3 0}$ & $\mathbf{1 0 0 \%}$ & $\mathbf{3 5}$ & $\mathbf{1 0 0 \%}$ \\
\hline
\end{tabular}

Dari tabel 4 diatas berdasarkan karakteristik usia diketahui bahwa pegawai tetap kebersihan prosentasi tertinggi berada di usia 46 - 50 tahun yaitu sebanyak 37\%, sedangkan pegawai outsourcing kebersihan porsentasi tertinggi berada di usia 20 25 tahun sebanyak 37\% juga.

Tabel 5

Karakteristik Responden Berdasarkan Pendidikan

\begin{tabular}{ccccc}
\hline \multirow{2}{*}{ Pendidikan } & \multicolumn{2}{c}{$\begin{array}{c}\text { Pegawai } \\
\text { Tetap }\end{array}$} & \multicolumn{2}{c}{$\begin{array}{c}\text { Pegawai } \\
\text { Outsourcing }\end{array}$} \\
\cline { 2 - 5 } & Jml & $\mathbf{( \% )}$ & Jml & $\mathbf{( \% )}$ \\
\hline SD & 4 & $13 \%$ & 0 & $0 \%$ \\
\hline SMP & 11 & $37 \%$ & 3 & $9 \%$ \\
\hline SMA & 15 & $50 \%$ & 32 & $91 \%$ \\
\hline Total & $\mathbf{3 0}$ & $\mathbf{1 0 0 \%}$ & $\mathbf{3 5}$ & $\mathbf{1 0 0 \%}$ \\
\hline
\end{tabular}

Dari tabel 5 diatas berdasarkan karakteristik pendidikan 50\% pegawai tetap kebersihan berpendidikan SMA sedangkan untuk pegawai outsourcing 91\% berpendidikan SMA.

Tabel 6

Karakteristik Responden Berdasarkan Status Perkawinan

\begin{tabular}{ccccc}
\hline \multirow{2}{*}{$\begin{array}{c}\text { Status } \\
\text { Perkawinan }\end{array}$} & \multicolumn{2}{c}{$\begin{array}{c}\text { Pegawai } \\
\text { Tetap }\end{array}$} & \multicolumn{2}{c}{$\begin{array}{c}\text { Pegawai } \\
\text { Outsourcing }\end{array}$} \\
\cline { 2 - 5 } & Jml & $\mathbf{( \% )}$ & Jml & $\mathbf{( \% )}$ \\
\hline Lajang & 2 & $7 \%$ & 11 & $31 \%$ \\
\hline Menikah & 26 & $87 \%$ & 23 & $66 \%$ \\
\hline Janda/Duda & 2 & $7 \%$ & 1 & $3 \%$ \\
\hline Total & $\mathbf{3 0}$ & $\mathbf{1 0 0 \%}$ & $\mathbf{3 5}$ & $\mathbf{1 0 0 \%}$ \\
\hline
\end{tabular}

Dari tabel 6 diatas berdasarkan karakteristik status perkawinan $87 \%$ pegawai tetap kebersihan berstatus menikah sedangkan untuk pegawai outsourcing $66 \%$ berstatus menikah.

Tabel 7

Karakteristik Responden Berdasarkan Lama Bekerja

\begin{tabular}{ccccc}
\hline \multirow{2}{*}{$\begin{array}{c}\text { Lama } \\
\text { Bekerja }\end{array}$} & \multicolumn{2}{c}{$\begin{array}{c}\text { Pegawai } \\
\text { Tetap }\end{array}$} & \multicolumn{2}{c}{$\begin{array}{c}\text { Pegawai } \\
\text { Outsourcing }\end{array}$} \\
\cline { 2 - 5 } & Jml & $\mathbf{( \% )}$ & Jml & $\mathbf{( \% )}$ \\
\hline $1-5$ & 0 & $0 \%$ & 35 & $100 \%$ \\
\hline
\end{tabular}




\begin{tabular}{ccccc}
$6-10$ & 0 & $0 \%$ & 0 & $0 \%$ \\
\hline $11-15$ & 2 & $7 \%$ & 0 & $0 \%$ \\
\hline $16-20$ & 18 & $60 \%$ & 0 & $0 \%$ \\
\hline $21-25$ & 8 & $27 \%$ & 0 & $0 \%$ \\
\hline $26-30$ & 1 & $3 \%$ & 0 & $0 \%$ \\
\hline $31-35$ & 1 & $3 \%$ & 0 & $0 \%$ \\
\hline Total & $\mathbf{3 0}$ & $\mathbf{1 0 0 \%}$ & $\mathbf{3 5}$ & $\mathbf{1 0 0 \%}$
\end{tabular}

Dari tabel 7 diatas berdasarkan karakteristik lama bekerja $60 \%$ pegawai tetap kebersihan telah bekerja di Universitas Widyatama selama 16 20 tahun, sedangkan pegawai outsourcing bagian kebersihan 100\% telah bekerja antara $1-5$ tahun.

\section{B. Analisis Deskriptif}

Berikut Analisis Deskriptif dari hasil kuesioner mengenai pelaksanaan Analisis Perbandingan Pegawai Tetap dan Pegawai Outsourcing bagian Kebersihan Ditinjau Dari Pemberdaya an, Kepuasan Kerja Dan Komitmen Organisasi (Studi Kasus Universitas Widyatama Bandung).

\section{Pemberdayaan}

Tanggapan responden pegawai tetap tentang pemberdayaan dapat dilihat padatabel dibawah sebagai berikut:

Tabel 8

Tanggapan Responden Pegawai Tetap atas Variabel Pemberdayaan

\begin{tabular}{|c|c|c|c|c|c|c|c|c|}
\hline $\begin{array}{c}\mathbf{N} \\
\mathbf{0}\end{array}$ & Penyataan & $\begin{array}{l}\mathbf{S} \\
\mathbf{T} \\
\mathbf{S} \\
\end{array}$ & TS & $\mathbf{N}$ & $\mathbf{S}$ & SS & Jml & $\begin{array}{c}\text { Rata } \\
\text { - } \\
\text { rata }\end{array}$ \\
\hline \multicolumn{9}{|c|}{ PEMBERDAYAAN } \\
\hline 1 & $\begin{array}{l}\text { Pekerjaan } \\
\text { yang } \\
\text { dilakukan } \\
\text { memiliki } \\
\text { makna } \\
\text { pribadi } \\
\text { untuk saya }\end{array}$ & 2 & 10 & 9 & 80 & 0 & 101 & 1.01 \\
\hline 2 & $\begin{array}{l}\text { saya } \\
\text { memiliki } \\
\text { rasa percaya } \\
\text { diri terhadap } \\
\text { kemampuan } \\
\text { saya dalam } \\
\text { melakukan } \\
\text { pekerjaan } \\
\text { dan selalu } \\
\text { yakin dapat }\end{array}$ & 1 & 4 & 6 & 80 & 25 & 116 & 1.16 \\
\hline
\end{tabular}

\begin{tabular}{|c|c|c|c|c|c|c|c|c|}
\hline $\begin{array}{l}\mathbf{N} \\
\mathbf{0}\end{array}$ & Penyataan & $\begin{array}{l}\mathbf{S} \\
\mathbf{T} \\
\mathbf{S}\end{array}$ & TS & $\mathbf{N}$ & $\mathbf{S}$ & SS & Jml & $\begin{array}{c}\text { Rata } \\
- \\
\text { rata }\end{array}$ \\
\hline & $\begin{array}{l}\text { mencapai } \\
\text { pekerjaan } \\
\text { yang telah } \\
\text { ditargetkan }\end{array}$ & & & & & & & \\
\hline 3 & $\begin{array}{l}\text { saya } \\
\text { memiliki hak } \\
\text { dalam } \\
\text { menentukan } \\
\text { bagaimana } \\
\text { cara saya } \\
\text { melakukan } \\
\text { pekerjaan }\end{array}$ & 0 & 4 & 6 & 88 & 20 & 118 & 1.18 \\
\hline 4 & $\begin{array}{l}\text { saya sangat } \\
\text { menyukai } \\
\text { segala } \\
\text { sesuatu yang } \\
\text { terjadi di } \\
\text { dalam unit } \\
\text { kerja saya } \\
\text { (bagian } \\
\text { kebersihan) }\end{array}$ & 1 & 0 & 27 & 72 & 10 & 110 & 1.1 \\
\hline & Jumlah & 4 & 18 & 48 & $\begin{array}{c}32 \\
0 \\
\end{array}$ & 55 & 445 & $\begin{array}{c}14.8 \\
3 \\
\end{array}$ \\
\hline & Rata-rata & & & & & & & 3.71 \\
\hline
\end{tabular}

Pada Tabel 8 dapat dilihat bahwa dari 4 (empat) item pertanyaan yang diajukan kepada responden pegawai tetap perihal variabel Pemberdayaan ternyata sebagian besar responden pengawai tetap berpendapat baik terhadap variabel Pemberdayaan karena nilai rata-rata dari keseluruhan pernyataan adalah sebesar 3,71 berada pada interval 3,40-4,19.

Sedangkan tanggapan responden pegawai outsourcing terhadap variabel pemberdayaan dapat dilihat pada tabel dibawah sebagai berikut:

Tabel 9

Tanggapan Responden Pegawai Outsourcing atas Variabel Pemberdayaan

\begin{tabular}{cllllllll}
\hline No & Penyataan & $\begin{array}{c}\text { ST } \\
\text { P }\end{array}$ & TS & N & S & SS & Jml & $\begin{array}{r}\text { Rata } \\
\text {-rata }\end{array}$ \\
\hline PEMBERDAYAAN & & & & & & & \\
\hline 1 & $\begin{array}{l}\text { Pekerjaan } \\
\text { yang } \\
\text { dilakukan } \\
\text { memiliki } \\
\text { makna } \\
\text { pribadi } \\
\text { untuk saya }\end{array}$ & 0 & 0 & 12 & 88 & 45 & 145 & 1.45 \\
\hline 2 & $\begin{array}{l}\text { saya } \\
\text { memiliki } \\
\text { rasa }\end{array}$ & 0 & 0 & 12 & 92 & 40 & 144 & 1.44 \\
\hline
\end{tabular}




\begin{tabular}{|c|c|c|c|c|c|c|c|c|}
\hline No & Penyataan & $\begin{array}{c}\text { ST } \\
\text { S }\end{array}$ & TS & $\mathbf{N}$ & $\mathbf{S}$ & SS & Jml & $\begin{array}{l}\text { Rata } \\
\text {-rata }\end{array}$ \\
\hline & $\begin{array}{l}\text { percaya diri } \\
\text { terhadap } \\
\text { kemampuan } \\
\text { saya dalam } \\
\text { melakukan } \\
\text { pekerjaan } \\
\text { dan selalu } \\
\text { yakin dapat } \\
\text { mencapai } \\
\text { pekerjaan } \\
\text { yang telah } \\
\text { ditargetkan }\end{array}$ & & & & & & & \\
\hline 3 & $\begin{array}{l}\text { saya } \\
\text { memiliki } \\
\text { hak dalam } \\
\text { menentukan } \\
\text { bagaimana } \\
\text { cara saya } \\
\text { melakukan } \\
\text { pekerjaan }\end{array}$ & 1 & 0 & 21 & 96 & 15 & 133 & 1.33 \\
\hline \multirow[t]{3}{*}{4} & $\begin{array}{l}\text { saya sangat } \\
\text { menyukai } \\
\text { segala } \\
\text { sesuatu } \\
\text { yang terjadi } \\
\text { di dalam } \\
\text { unit kerja } \\
\text { saya } \\
\text { (bagian } \\
\text { kebersihan) }\end{array}$ & 1 & 2 & 24 & 64 & 45 & 136 & 1.36 \\
\hline & Jumlah & 2 & 2 & 69 & $\begin{array}{c}34 \\
0\end{array}$ & $\begin{array}{c}14 \\
5 \\
\end{array}$ & 558 & $\begin{array}{c}15.9 \\
4 \\
\end{array}$ \\
\hline & Rata-rata & & & & & & & 3.99 \\
\hline
\end{tabular}

Pada Tabel 9 dapat dilihat bahwa dari 4 (empat) item pertanyaan yang diajukan kepada responden pegawai outsourcing perihal variabel Pemberdayaan ternyata sebagian besar responden pengawai outsourcing berpendapat baik terhadap variabel Pemberdayaan karena nilai rata-rata dari keseluruhan pernyataan adalah sebesar 3,99 berada pada interval $3,40-4,19$.

\section{Dilihat dari variabel pemberdayaan skor rata-rata} variabel pemberdayaan pegawai outsourcing memiliki skor lebih besar yaitu 3,99 dibandingkan pegawai tetap yang memiliki skor 3,71 .

Dari 4 point pertanyaan variabel Pemberdayaan, manajemen Universitas Widyatama harus memperhatikan pendapat sangat tidak setuju pegawai tetap sebanyak 2 orang atas pernyataan "Pekerjaan yang dilakukan memiliki makna pribadi untuk saya", sedangkan pendapat sangat tidak setuju pegawai outsourcing sebanyak 1 orang atas pernyataan "saya memiliki hak dalam menentukan bagaimana cara saya melakukan pekerjaan"dan "saya sangat menyukai segala sesuatu yang terjadi di dalam unit kerja saya (bagian kebersihan)".

\section{Kepuasan Kerja}

Tanggapan

responden

pegawai tetap tentang Kepuasan Kerja dapat dilihat pada tabel dibawah sebagai berikut:

\section{Tabel 10}

Tanggapan Responden Pegawai Tetap atas Variabel Kepuasan Kerja

\begin{tabular}{|c|c|c|c|c|c|c|c|c|}
\hline $\begin{array}{l}\mathbf{N} \\
\mathbf{0}\end{array}$ & Penyataan & $\begin{array}{c}\text { ST } \\
\text { S }\end{array}$ & TS & $\mathbf{N}$ & $\mathbf{S}$ & SS & Jml & $\begin{array}{l}\text { Rata } \\
\text {-rata }\end{array}$ \\
\hline \multicolumn{9}{|c|}{ KEPUASAN KERJA } \\
\hline 1 & $\begin{array}{l}\text { gaji yang } \\
\text { diterima } \\
\text { oleh saya } \\
\text { setara } \\
\text { dengan } \\
\text { beban } \\
\text { pekerjaan } \\
\text { yang } \\
\text { dilakukan } \\
\end{array}$ & 0 & 32 & 6 & 40 & 10 & 88 & 0.88 \\
\hline 2 & $\begin{array}{l}\text { Hanya ada } \\
\text { sedikit } \\
\text { kesempatan } \\
\text { promosi } \\
\text { jabatan } \\
\text { dalam } \\
\text { pekerjaan } \\
\text { saya }\end{array}$ & 0 & 6 & 9 & 84 & 15 & 114 & 1.14 \\
\hline 3 & $\begin{array}{l}\text { atasan saya } \\
\text { memiliki } \\
\text { cara yang } \\
\text { cukup } \\
\text { kompeten } \\
\text { dalam } \\
\text { menangani } \\
\text { para } \\
\text { pegawainya }\end{array}$ & 1 & 18 & 27 & 24 & 25 & 95 & 0.95 \\
\hline 4 & $\begin{array}{l}\text { saya merasa } \\
\text { puas } \\
\text { dengan } \\
\text { tunjangan } \\
\text { yang } \\
\text { diterima }\end{array}$ & 3 & 20 & 30 & 28 & 0 & 81 & 0.81 \\
\hline 5 & $\begin{array}{l}\text { saya } \\
\text { mendapatka }\end{array}$ & 2 & 34 & 3 & 32 & 10 & 81 & 0.81 \\
\hline
\end{tabular}




\begin{tabular}{|c|c|c|c|c|c|c|c|c|}
\hline $\begin{array}{l}\mathbf{N} \\
\mathbf{0}\end{array}$ & Penyataan & $\begin{array}{c}\text { ST } \\
\text { S }\end{array}$ & TS & $\mathbf{N}$ & $\mathbf{S}$ & SS & Jml & $\begin{array}{l}\text { Rata } \\
\text {-rata }\end{array}$ \\
\hline & $\begin{array}{l}\mathrm{n} \\
\text { penghargaa } \\
\mathrm{n} / \text { pengakua } \\
\mathrm{n} \text { ketika } \\
\text { melakukan } \\
\text { pekerjaan } \\
\text { dengan baik }\end{array}$ & & & & & & & \\
\hline 6 & $\begin{array}{l}\text { Dengan } \\
\text { adanya } \\
\text { peraturan } \\
\text { dan } \\
\text { prosedur } \\
\text { operasional, } \\
\text { membuat } \\
\text { saya } \\
\text { melakukan } \\
\text { pekerjaan } \\
\text { dengan baik }\end{array}$ & 1 & 0 & 27 & 72 & 10 & 110 & 1.1 \\
\hline 7 & $\begin{array}{l}\text { saya dapat } \\
\text { bekerjasam } \\
\text { a dengan } \\
\text { baik dengan } \\
\text { rekan kerja } \\
\text { saya }\end{array}$ & 1 & 4 & 6 & 80 & 25 & 116 & 1.16 \\
\hline 8 & $\begin{array}{l}\text { saya merasa } \\
\text { pekerjaan } \\
\text { yang } \\
\text { dikerjakan } \\
\text { tidak } \\
\text { berarti/tidak } \\
\text { dihargai }\end{array}$ & 2 & 10 & 9 & 80 & 0 & 101 & 1.01 \\
\hline 9 & $\begin{array}{l}\text { Saya } \\
\text { merasa } \\
\text { komunikasi } \\
\text { yang } \\
\text { terjalin } \\
\text { antara } \\
\text { seluruh } \\
\text { anggota } \\
\text { organisasi } \\
\text { di dalam } \\
\text { perusahaan } \\
\text { sudah baik }\end{array}$ & 0 & 6 & 9 & 84 & 15 & 114 & 1.14 \\
\hline & Jml & 10 & $\begin{array}{c}13 \\
0\end{array}$ & 126 & $\begin{array}{c}52 \\
4 \\
\end{array}$ & $\begin{array}{c}11 \\
0\end{array}$ & 900 & 30.00 \\
\hline & Rata-rata & & & & & & & 3.33 \\
\hline
\end{tabular}

Pada Tabel 10 dapat dilihat bahwa dari 9 (sembilan) item pertanyaan yang diajukan kepada responden pegawai tetap perihal variabel Kepuasan Kerja ternyata sebagian besar responden pengawai tetap berpendapat cukup baik terhadap variabel Kepuasan Kerja karena nilai rata-rata dari keseluruhan pernyataan adalah sebesar 3,33 berada pada interval $2,60-3,39$.

Sedangkan tanggapan responden pegawai outsourcing terhadap variabel Kepuasan Kerja dapat dilihat pada tabel dibawah sebagai berikut:

Tabel 11

Tanggapan Responden Pegawai Outsourcing atas Variabel Kepuasan Kerja

\begin{tabular}{|c|c|c|c|c|c|c|c|c|}
\hline $\begin{array}{l}\mathbf{N} \\
\mathbf{0}\end{array}$ & Penyataan & $\begin{array}{c}\text { ST } \\
\text { S }\end{array}$ & $\begin{array}{l}T \\
S\end{array}$ & $\mathbf{N}$ & $\mathbf{S}$ & SS & Jml & $\begin{array}{l}\text { Rata } \\
\text {-rata }\end{array}$ \\
\hline \multicolumn{9}{|c|}{ KEPUASAN KERJA } \\
\hline 1 & $\begin{array}{l}\text { gaji yang } \\
\text { diterima } \\
\text { oleh saya } \\
\text { setara } \\
\text { dengan } \\
\text { beban } \\
\text { pekerjaan } \\
\text { yang } \\
\text { dilakukan }\end{array}$ & 3 & 8 & 27 & 56 & 25 & 119 & 1.19 \\
\hline 2 & Hanya ada & & & & & & & \\
\hline
\end{tabular}

sedikit

kesempatan

$\begin{array}{llllllll}\text { promosi } & 3 & 8 & 30 & 64 & 10 & 115 & 1.15\end{array}$

jabatan

dalam

pekerjaan

saya

3 atasan saya

memiliki

cara yang

cukup

$\begin{array}{llllllll}\text { kompeten } & 0 & 1 & 45 & 40 & 25 & 120 & 1.2\end{array}$

dalam

menangani

para

pegawainya

4 saya merasa

puas

dengan

tunjangan

yang

diterima

$5 \quad$ saya

n

penghargaa

$\begin{array}{llllllll}\text { n/pengakua } & 3 & 8 & 30 & 64 & 10 & 115 & 1.15\end{array}$

n ketika

melakukan

pekerjaan

dengan baik

6 Dengan

adanya

peraturan

dan

$\begin{array}{llllclll}\begin{array}{l}\text { prosedur } \\ \text { operasional, }\end{array} & 1 & 0 & 24 & \begin{array}{c}10 \\ 0\end{array} & 5 & 130 & 1.3\end{array}$

membuat

saya

melakukan

pekerjaan

dengan baik

7 saya dapat

bekerjasam

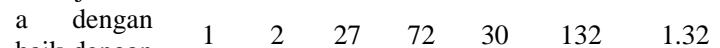

baik dengan

rekan kerja

saya

\begin{tabular}{lllllllll}
\hline 8 & $\begin{array}{l}\text { saya merasa } \\
\text { pekerjaan } \\
\text { yang }\end{array}$ & 1 & 6 & 42 & 68 & 0 & 117 & 1.17 \\
\hline
\end{tabular}




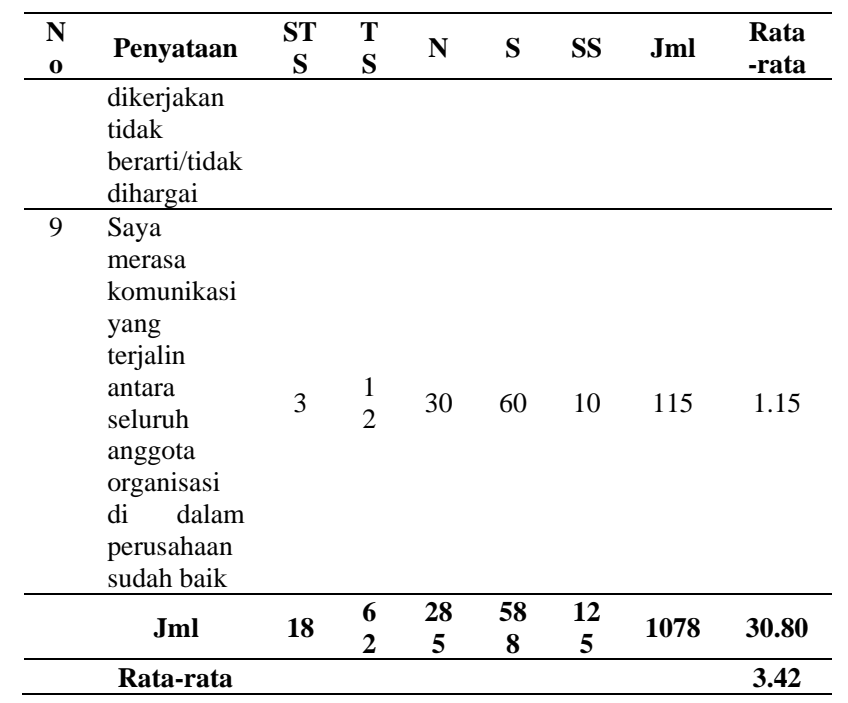

Pada Tabel 11 dapat dilihat bahwa dari 9 (sembilan) item pertanyaan yang diajukan kepada responden pegawai outsourcing perihal variabel Kepuasan Kerja ternyata sebagian besar responden pengawai outsourcing berpendapat baik terhadap variabel Kepuasan Kerja karena nilai rata-rata dari keseluruhan pernyataan adalah sebesar 3,42 berada pada interval $3,40-4,19$.

Dilihat dari variabel Kepuasan Kerja skor rata-rata variabel Kepuasan Kerja pegawai outsourcing memiliki skor lebih besar yaitu 3,42dibandingkan pegawai tetap yang memiliki skor 3,33 .

Dari 9 point pertanyaan variabel Kepuasan Kerja, manajemen Universitas Widyatama harus memperhatikan pendapat sangat tidak setuju pegawai outsourcing sebanyak 3 orang atasbeberapa pernyataan "gaji yang diterima oleh saya setara dengan beban pekerjaan yang dilakukan", "Hanya ada sedikit kesempatan promosi jabatan dalam pekerjaan saya", "saya merasa puas dengan tunjangan yang diterima", "saya mendapatkan penghargaan/pengaku an ketika melakukan pekerjaan dengan baik" dan "Saya merasa komunikasi yang terjalin antara seluruh anggota organisasi di dalam perusahaan sudah baik“, sedangkan pendapat sangat tidak setuju pegawai tetap sebanyak 3 orang atas pernyataan "saya merasa puas dengan tunjangan yang diterima".

\section{Komitmen Organisasi}

Tanggapan responden pegawai tetap tentang Komitmen Organisasi dapat dilihat pada tabel dibawah sebagai berikut:

Tabel 12

Tanggapan Responden Pegawai Tetap atas Variabel Komitmen Organisasi

\begin{tabular}{|c|c|c|c|c|c|c|c|c|}
\hline $\begin{array}{c}\mathbf{N} \\
\mathbf{0} \\
\end{array}$ & Penyataan & $\begin{array}{c}\text { ST } \\
\text { S }\end{array}$ & $\begin{array}{l}\mathbf{T} \\
\mathbf{S}\end{array}$ & $\mathbf{N}$ & $\mathbf{S}$ & SS & Jml & $\begin{array}{l}\text { Rata } \\
\text {-rata }\end{array}$ \\
\hline \multicolumn{9}{|c|}{ KOMITMEN ORGANISASI } \\
\hline 1 & $\begin{array}{l}\text { saya merasa } \\
\text { senang jika } \\
\text { menghabiska } \\
\mathrm{n} \text { sisa karir } \\
\text { di } \\
\text { perusahaan } \\
\text { tempat } \\
\text { bekerja dan } \\
\text { memiliki } \\
\text { ikatan secara } \\
\text { emosional } \\
\text { dengan } \\
\text { perusahaan } \\
\text { tempat saya } \\
\text { bekerja }\end{array}$ & 0 & 6 & 9 & 84 & 15 & 114 & 1.14 \\
\hline 2 & $\begin{array}{l}\text { saya } \\
\text { memegang } \\
\text { teguh visi } \\
\text { dan misi } \\
\text { dalam } \\
\text { melaksanaka } \\
\mathrm{n} \text { pekerjaan } \\
\text { sehari-hari } \\
\text { dan merasa } \\
\text { masalah } \\
\text { yang } \\
\text { dihadapi } \\
\text { perusahaan } \\
\text { juga } \\
\text { merupakan } \\
\text { masalah saya }\end{array}$ & 0 & 2 & 15 & 88 & 10 & 115 & 1.15 \\
\hline 3 & $\begin{array}{l}\text { saya tidak } \\
\text { rela } \\
\text { kehilangan } \\
\text { hubungan } \\
\text { persahabatan }\end{array}$ & 0 & 6 & 9 & 84 & 15 & 114 & 1.14 \\
\hline
\end{tabular}




\begin{tabular}{|c|c|c|c|c|c|c|c|c|}
\hline $\begin{array}{l}\mathbf{N} \\
\mathbf{0}\end{array}$ & Penyataan & $\begin{array}{c}\text { ST } \\
\text { S }\end{array}$ & $\begin{array}{l}\mathbf{T} \\
\mathbf{S}\end{array}$ & $\mathbf{N}$ & $\mathbf{S}$ & SS & Jml & $\begin{array}{l}\text { Rata } \\
\text {-rata }\end{array}$ \\
\hline & $\begin{array}{l}\text { dengan rekan } \\
\text { kerja saya } \\
\text { apabila } \\
\text { keluar dari } \\
\text { perusahaan } \\
\text { tempat saya } \\
\text { bekerja saat } \\
\text { ini dan } \\
\text { enggan } \\
\text { mencari } \\
\text { pekerjaan di } \\
\text { perusahaan } \\
\text { lain karena } \\
\text { sudah } \\
\text { nyaman } \\
\text { dengan } \\
\text { perusahaan } \\
\text { tempat } \\
\text { bekerja saat } \\
\text { ini }\end{array}$ & & & & & & & \\
\hline & Jml & 0 & $\begin{array}{l}1 \\
4\end{array}$ & 33 & $\begin{array}{c}25 \\
6\end{array}$ & 40 & 343 & $\begin{array}{c}11.4 \\
3\end{array}$ \\
\hline & Rata-rata & & & & & & & 3.81 \\
\hline
\end{tabular}

Pada Tabel 12 dapat dilihat bahwa dari 3 (tiga) item pertanyaan yang diajukan kepada responden pegawai tetap perihal variabel Komitmen Organisasi ternyata sebagian besar responden pengawai tetap berpendapat baik terhadap variabel Pemberdayaan karena nilai rata-rata dari keseluruhan pernyataan adalah sebesar 3,84 berada pada interval 3,40-4,19.

Sedangkan tanggapan responden pegawai outsourcing terhadap variabel Komitmen Organisasi dapat dilihat pada tabel dibawah sebagai berikut:

Tabel 13

Tanggapan Responden Pegawai Outsourcing atas Variabel Komitmen Organisasi

\begin{tabular}{|c|c|c|c|c|c|c|c|c|}
\hline $\begin{array}{l}\mathbf{N} \\
\mathbf{0}\end{array}$ & Penyataan & $\begin{array}{c}\text { ST } \\
\text { S }\end{array}$ & $\begin{array}{l}\mathbf{T} \\
\mathbf{S}\end{array}$ & $\mathbf{N}$ & $\mathbf{S}$ & SS & Jml & $\begin{array}{l}\text { Rata } \\
\text { rata }\end{array}$ \\
\hline \multicolumn{9}{|c|}{ KOMITMEN ORGANISASI } \\
\hline 1 & $\begin{array}{l}\text { saya merasa } \\
\text { senang jika } \\
\text { menghabisk } \\
\text { an sisa karir } \\
\text { di } \\
\text { perusahaan } \\
\text { tempat } \\
\text { bekerja dan } \\
\text { memiliki } \\
\text { ikatan } \\
\text { secara } \\
\text { emosional }\end{array}$ & 6 & 8 & 42 & 24 & 25 & 105 & 1.05 \\
\hline
\end{tabular}

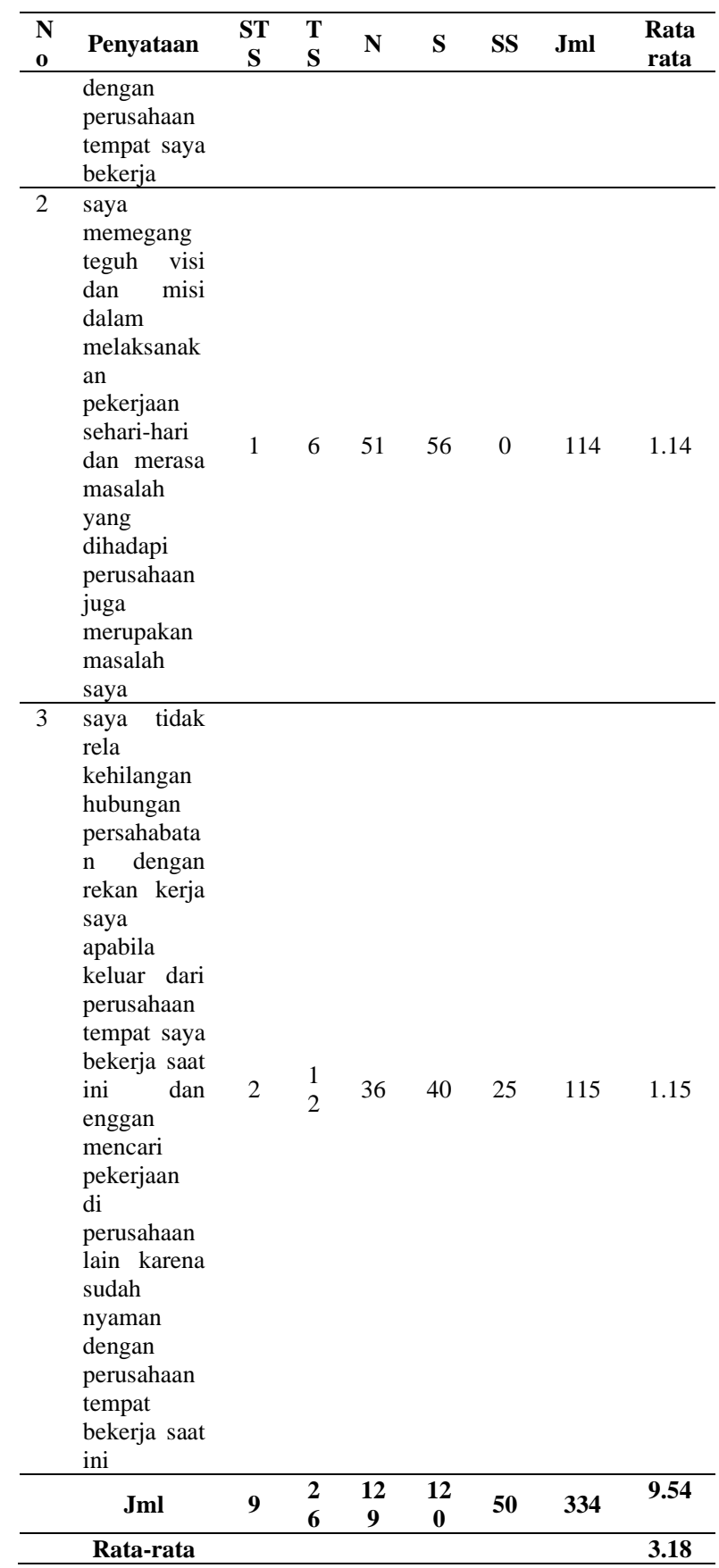

Pada Tabel 13 dapat dilihat bahwa dari 3 (tiga) item pertanyaan yang diajukan kepada responden pegawai outsourcing perihal variabel Komitmen Organisasi ternyata sebagian besar responden pengawai outsourcing berpendapat cukup baik terhadap variabel Komitmen Organisasi karena nilai rata-rata dari keseluruhan 
pernyataan adalah sebesar 3,18 berada pada interval 2,60-3,39.

Dilihat dari variabel Komitmen Organisasi skor rata-rata variabel Komitmen Organisasi pegawai tetap memiliki skor lebih besar yaitu 3,84 dibandingkan pegawai outsourcing yang memiliki skor 3,18 .

Dari 3point pertanyaan variabel Komitmen Organisasi, manajemen Universitas Widyatama harus memperhatikan pendapat sangat tidak setuju pegawai outsourcing sebanyak 6 orang atas pernyataan "saya merasa senang jika menghabiskan sisa karir di perusahaan tempat bekerja dan memiliki ikatan secara emosional dengan perusahaan tempat saya bekerja".

Dalam melakukan uji validitas dan reliabilitas, penulis menggunakan alat bantu SPSS 23.00. Hasil pengujian validitas selanjutnya dapat dilihat selengkapnya pada tabel dibawah ini:

\section{a. Pemberdayaan}

Hasil uji validitas untuk pemberdayaan pegawai tetap bagian kebersihan Universitas Widyatama adalah seperti yang terlihat pada tabel 14 dibawah ini:

Tabel 14

Hasil Uji Validitas Pemberdayaan Pegawai Tetap

\begin{tabular}{clccc}
\hline No. & \multicolumn{1}{c}{ Pernyataan } & $\begin{array}{c}\mathbf{r} \\
\text { Hitung }\end{array}$ & $\begin{array}{c}\mathbf{r} \\
\text { Tabel }\end{array}$ & Ket \\
\hline 1 & $\begin{array}{l}\text { Pekerjaan yang } \\
\text { dilakukan memiliki } \\
\text { makna pribadi untuk } \\
\text { saya }\end{array}$ & 0.761 & 0.361 & Valid \\
\hline 2 & $\begin{array}{l}\text { saya memiliki rasa } \\
\text { percaya diri terhadap } \\
\text { kemampuan saya dalam } \\
\text { melakukan pekerjaan } \\
\text { dan selalu yakin dapat } \\
\text { mencapai pekerjaan } \\
\text { yang telah ditargetkan }\end{array}$ & 0.546 & 0.361 & Valid \\
\hline 3 & $\begin{array}{l}\text { saya memiliki hak dalam } \\
\text { menentukan bagaimana } \\
\text { cara saya melakukan } \\
\text { pekerjaan }\end{array}$ & 0.508 & 0.361 & Valid \\
\hline & & & \\
\hline
\end{tabular}

4 saya sangat menyukai segala sesuatu yang terjadi di dalam unit kerja saya (bagian kebersihan)

Hasil uji validitas untuk pemberdayaan pegawai outsourcing bagian kebersihan Universitas Widyatama adalah seperti yang terlihat pada tabel 15 dibawah ini:

Tabel 15

Hasil Uji Validitas Pemberdayaan Pegawai Outsourcing

\begin{tabular}{|c|c|c|c|c|}
\hline No. & Pernyataan & r Hitung & r Tabel & Ket \\
\hline 1 & $\begin{array}{l}\text { Pekerjaan yang } \\
\text { dilakukan } \\
\text { memiliki makna } \\
\text { pribadi untuk } \\
\text { saya }\end{array}$ & 0.540 & 0.334 & Valid \\
\hline 2 & $\begin{array}{l}\text { saya memiliki } \\
\text { rasa percaya diri } \\
\text { terhadap } \\
\text { kemampuan saya } \\
\text { dalam } \\
\text { melakukan } \\
\text { pekerjaan dan } \\
\text { selalu yakin } \\
\text { dapat mencapai } \\
\text { pekerjaan yang } \\
\text { telah ditargetkan }\end{array}$ & 0.578 & 0.334 & Valid \\
\hline 3 & $\begin{array}{l}\text { saya memiliki } \\
\text { hak dalam } \\
\text { menentukan } \\
\text { bagaimana cara } \\
\text { saya melakukan } \\
\text { pekerjaan }\end{array}$ & 0.547 & 0.334 & Valid \\
\hline 4 & $\begin{array}{l}\text { saya sangat } \\
\text { menyukai segala } \\
\text { sesuatu yang } \\
\text { terjadi di dalam } \\
\text { unit kerja saya } \\
\text { (bagian } \\
\text { kebersihan) }\end{array}$ & 0.617 & 0.334 & Valid \\
\hline
\end{tabular}

\section{b. Kepuasan Kerja}

Hasil uji validitas untuk Kepuasan Kerja pegawai tetap bagian kebersihan Universitas Widyatama adalah seperti yang terlihat pada tabel 16 dibawah ini:

Tabel 16

Hasil Uji Validitas Kepuasan Kerja Pegawai Tetap

\begin{tabular}{clccc}
\hline No. & \multicolumn{1}{c}{ Pernyataan } & $\begin{array}{c}\mathbf{r} \\
\text { Hitung }\end{array}$ & $\begin{array}{c}\mathbf{r} \\
\text { Tabel }\end{array}$ & Ket \\
\hline 1 & $\begin{array}{l}\text { gaji yang diterima oleh } \\
\text { saya setara dengan } \\
\text { beban pekerjaan yang } \\
\text { dilakukan }\end{array}$ & 0.651 & 0.361 & Valid \\
\hline 2 & $\begin{array}{l}\text { Hanya ada sedikit } \\
\text { kesempatan promosi } \\
\text { jabatan dalam pekerjaan }\end{array}$ & 0.547 & 0.361 & Valid \\
\hline
\end{tabular}




\begin{tabular}{|c|c|c|c|c|}
\hline No. & Pernyataan & $\begin{array}{c}\mathbf{r} \\
\text { Hitung }\end{array}$ & $\begin{array}{c}\mathbf{r} \\
\text { Tabel }\end{array}$ & Ket \\
\hline & saya & & & \\
\hline 3 & $\begin{array}{l}\text { atasan saya memiliki } \\
\text { cara yang cukup } \\
\text { kompeten dalam } \\
\text { menangani para } \\
\text { pegawainya }\end{array}$ & 0.633 & 0.361 & Valid \\
\hline 4 & $\begin{array}{l}\text { saya merasa puas } \\
\text { dengan tunjangan yang } \\
\text { diterima }\end{array}$ & 0.682 & 0.361 & Valid \\
\hline 5 & $\begin{array}{l}\text { saya mendapatkan } \\
\text { penghargaan/pengakuan } \\
\text { ketika melakukan } \\
\text { pekerjaan dengan baik }\end{array}$ & 0.645 & 0.361 & Valid \\
\hline 6 & $\begin{array}{l}\text { Dengan adanya } \\
\text { peraturan dan prosedur } \\
\text { operasional, membuat } \\
\text { saya melakukan } \\
\text { pekerjaan dengan baik }\end{array}$ & 0.432 & 0.361 & Valid \\
\hline 7 & $\begin{array}{l}\text { saya dapat bekerjasama } \\
\text { dengan baik dengan } \\
\text { rekan kerja saya }\end{array}$ & 0.390 & 0.361 & Valid \\
\hline 8 & $\begin{array}{l}\text { saya merasa pekerjaan } \\
\text { yang dikerjakan tidak } \\
\text { berarti/tidak dihargai }\end{array}$ & 0.556 & 0.361 & Valid \\
\hline 9 & $\begin{array}{l}\text { Saya merasa } \\
\text { komunikasi yang } \\
\text { terjalin antara seluruh } \\
\text { anggota organisasi di } \\
\text { dalam perusahaan } \\
\text { sudah baik }\end{array}$ & 0.547 & 0.361 & Valid \\
\hline
\end{tabular}

Hasil uji validitas untuk kepuasan kerja pegawai outsourcing bagian kebersihan Universitas Widyatama adalah seperti yang terlihat pada tabel 17 dibawah ini:

Tabel 17

Hasil Uji Validitas Kepuasan Kerja Pegawai Outsourcing

\begin{tabular}{|c|c|c|c|c|}
\hline No. & Pernyataan & $\begin{array}{c}\mathbf{r} \\
\text { Hitung }\end{array}$ & $\begin{array}{c}\mathbf{r} \\
\text { Tabel }\end{array}$ & Ket \\
\hline 1 & $\begin{array}{l}\text { gaji yang diterima oleh } \\
\text { saya setara dengan } \\
\text { beban pekerjaan yang } \\
\text { dilakukan }\end{array}$ & 0.383 & 0.334 & Valid \\
\hline 2 & $\begin{array}{l}\text { Hanya ada sedikit } \\
\text { kesempatan promosi } \\
\text { jabatan dalam pekerjaan } \\
\text { saya }\end{array}$ & 0.940 & 0.334 & Valic \\
\hline 3 & $\begin{array}{l}\text { atasan saya memiliki } \\
\text { cara yang cukup } \\
\text { kompeten dalam } \\
\text { menangani para } \\
\text { pegawainya }\end{array}$ & 0.591 & 0.334 & Valic \\
\hline 4 & $\begin{array}{l}\text { saya merasa puas } \\
\text { dengan tunjangan yang } \\
\text { diterima }\end{array}$ & 0.940 & 0.334 & Valid \\
\hline 5 & $\begin{array}{l}\text { saya mendapatkan } \\
\text { penghargaan/pengakuan } \\
\text { ketika melakukan } \\
\text { pekerjaan dengan baik }\end{array}$ & 0.940 & 0.334 & Valid \\
\hline 6 & $\begin{array}{l}\text { Dengan adanya } \\
\text { peraturan dan prosedur } \\
\text { operasional, membuat } \\
\text { saya melakukan } \\
\text { pekerjaan dengan baik }\end{array}$ & 0.527 & 0.334 & Valic \\
\hline
\end{tabular}

Tabel 17

Hasil Uji Validitas Kepuasan Kerja Pegawai Outsourcing

\begin{tabular}{clccc}
\hline No. & \multicolumn{1}{c}{$\begin{array}{c}\text { Pernyataan } \\
\text { Hitung }\end{array}$} & $\begin{array}{c}\text { r } \\
\text { Tabel }\end{array}$ & Ket \\
\cline { 5 - 5 } & $\begin{array}{l}\text { saya dapat bekerjasama } \\
\text { dengan baik dengan } \\
\text { rekan kerja saya }\end{array}$ & 0.446 & 0.334 & Valid \\
\hline 8 & $\begin{array}{l}\text { saya merasa pekerjaan } \\
\text { yang dikerjakan tidak } \\
\text { berarti/tidak dihargai }\end{array}$ & 0.360 & 0.334 & Valid \\
\hline 9 & $\begin{array}{l}\text { Saya merasa } \\
\text { komunikasi yang } \\
\text { terjalin antara seluruh } \\
\text { anggota organisasi di } \\
\text { dalam perusahaan } \\
\text { sudah baik }\end{array}$ & 0.940 & 0.334 & Valid \\
\hline
\end{tabular}

\section{c. Komitmen Organisasi}

Hasil uji validitas untuk Komitemen Organisasi pegawai tetap bagian kebersihan Universitas Widyatama adalah seperti yang terlihat pada tabel 18 dibawah ini:

Tabel 18

Hasil Uji Validitas Komitmen Organisasi Pegawai Tetap

\begin{tabular}{|c|c|c|c|c|}
\hline No. & Pernyataan & $\begin{array}{c}\mathbf{r} \\
\text { Hitung }\end{array}$ & $\begin{array}{c}\mathbf{r} \\
\text { Tabel }\end{array}$ & Ket \\
\hline 1 & $\begin{array}{l}\text { saya merasa senang } \\
\text { jika menghabiskan } \\
\text { sisa karir di } \\
\text { perusahaan tempat } \\
\text { bekerja dan memiliki } \\
\text { ikatan secara } \\
\text { emosional dengan } \\
\text { perusahaan tempat } \\
\text { saya bekerja }\end{array}$ & 0.984 & 0.361 & Valid \\
\hline 2 & $\begin{array}{l}\text { saya memegang teguh } \\
\text { visi dan misi dalam } \\
\text { melaksanakan } \\
\text { pekerjaan sehari-hari } \\
\text { dan merasa masalah } \\
\text { yang dihadapi } \\
\text { perusahaan juga } \\
\text { merupakan masalah } \\
\text { saya }\end{array}$ & 0.918 & 0.361 & Valid \\
\hline 3 & $\begin{array}{l}\text { saya tidak rela } \\
\text { kehilangan hubungan } \\
\text { persahabatan dengan } \\
\text { rekan kerja saya } \\
\text { apabila keluar dari } \\
\text { perusahaan tempat } \\
\text { saya bekerja saat ini } \\
\text { dan enggan mencari } \\
\text { pekerjaan di } \\
\text { perusahaan lain karena } \\
\text { sudah nyaman dengan } \\
\text { perusahaan tempat } \\
\text { bekerja saat ini }\end{array}$ & 0.984 & 0.361 & Valid \\
\hline
\end{tabular}

Hasil uji validitas untuk komitmen organisasi pegawai outsourcing bagian kebersihan 
Universitas Widyatama adalah seperti yang terlihat pada tabel 19 dibawah ini:

Tabel 19

Hasil Uji Validitas Komitmen Organisasi

\begin{tabular}{|c|c|c|c|c|}
\hline \multicolumn{5}{|c|}{ Pegawai Outsourcing } \\
\hline No & Pernyataan & $\begin{array}{c}\mathbf{r} \\
\text { Hitung }\end{array}$ & $\begin{array}{c}\mathbf{r} \\
\text { Tabel }\end{array}$ & Ket \\
\hline 1 & $\begin{array}{l}\text { saya merasa senang jika } \\
\text { menghabiskan sisa karir } \\
\text { di perusahaan tempat } \\
\text { bekerja dan memiliki } \\
\text { ikatan secara emosional } \\
\text { dengan perusahaan } \\
\text { tempat saya bekerja }\end{array}$ & 0.650 & 0.334 & Valid \\
\hline 2 & $\begin{array}{l}\text { saya memegang teguh } \\
\text { visi dan misi dalam } \\
\text { melaksanakan pekerjaan } \\
\text { sehari-hari dan merasa } \\
\text { masalah yang dihadapi } \\
\text { perusahaan juga } \\
\text { merupakan masalah } \\
\text { saya }\end{array}$ & 0.569 & 0.334 & Valid \\
\hline 3 & $\begin{array}{lr}\text { saya tidak rela } \\
\text { kehilangan hubungan } \\
\text { persahabatan dengan } \\
\text { rekan kerja saya apabila } \\
\text { keluar dari perusahaan } \\
\text { tempat saya bekerja saat } \\
\text { ini dan enggan mencari } \\
\text { pekerjaan di perusahaan } \\
\text { lain karena sudah } \\
\text { nyaman } & \text { dengan } \\
\text { perusahaan tempat } \\
\text { bekerja saat ini }\end{array}$ & 0.662 & 0.334 & Valid \\
\hline
\end{tabular}

\section{Uji Reliabilitas}

Reliabilitas menunjuk pada suatu pengertian bahwa sesuatu instrument dapat dipercaya untuk digunakan sebagai alat pengumpul data karena instrument tersebut sudah dianggap baik. Reliabel artinya dapat dipercaya juga dapat diandalkan, sehingga beberapa kali diulang pun hasilnya akan tetap sama (konsisten) (Syahrani, 2008).

Realibilitas suatu konstrukvariabel dikatakan baik jika memliki nilai cronbachalpa 0,60 (Nugroho, 2005). Hasil pengujian realibilitas untuk masing-masing variabel diringkas pada tabel 20 berikut ini:

Tabel 20

Hasil Pengujian Reliabilitas

\begin{tabular}{cccccc}
\hline \multirow{3}{*}{ No. } & \multirow{3}{*}{ Indikator } & \multicolumn{2}{c}{ Pegawai Tetap } & \multicolumn{2}{c}{$\begin{array}{c}\text { Pegawai } \\
\text { Outsourcing }\end{array}$} \\
\cline { 3 - 6 } & & cronbachs & N of & cronbachs & N of \\
& & alpa & Item & alpa & Item \\
\hline 1 & Pemberdayaan & 0.752 & 4 & 0.756 & 4 \\
\hline
\end{tabular}

\begin{tabular}{llllll}
2 & Kepuasan Kerja & 0.846 & 9 & 0.901 & 9 \\
\hline 3 & $\begin{array}{l}\text { Komitmen } \\
\text { Organisasi }\end{array}$ & 0.976 & 3 & 0.766 & 3 \\
\hline
\end{tabular}

Hasil uji realibilitas tersebut menunjukkan bahwa semua variabeldinyatakan realibel karena telah melewati batas koefisien realibilitas yaitu 0.60 sehinggauntuk selanjutnya item-item pada masing-masing konsep variabel tersebut layakdigunakan sebagai alat ukur.

\section{Teknik Analisis Data}

Uji-t pada penelitian ini melibatkan dua kelompok sampel pada penelitian yaitu pegawai tetap dan pegawai outsourcing. Uji-t ini dilakukan untuk mengetahui perbandingan paling signifikan dari jawaban-jawaban yang diberikan oleh kedua kelompok sampel tersebut terhadap variabel-variabel penelitian. Uji-tdilakukan dengan melihat hasil dari Levene's Test for Equality Variance kemudian dilanjutkan dengan meninjau hasil signifikansi dari ujit.

Tabel 21

Levene's Test dan $t$ Test Pemberdayaan

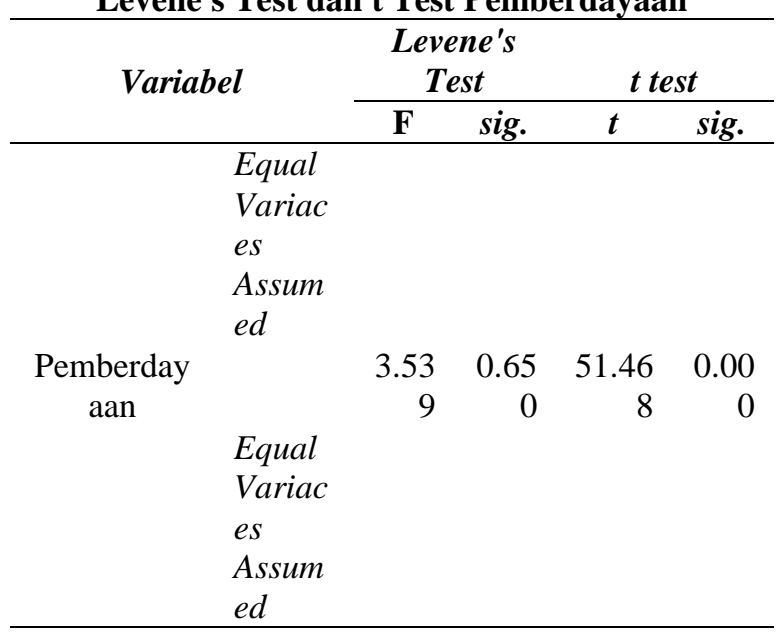

Hasil dari Levene's Test varibel pemberdayaan yang dilihat dari niliai Fhitung untuk asumsi varians adalah 3,539 dengan angka (Sig.) 0,650>0,05, yang berarti varians populasi dari kedua kelompok memiliki persamaan atau 
homogen. Kemudian hasil dari t-hitung variabel pemberdayaan adalah 51,468 dengan angka (Sig.) 0,000. Berdasarkan hasil angka (Sig.) 0,000< 0,05 maka H0 ditolak. Artinya terdapat perbedaan pemberdayaan antara pegawai tetap dengan pegawai outsourcing.

Tabel 22

Levene's Test dan t Test Kepuasan Kerja

\begin{tabular}{clcccc}
\hline \multirow{2}{*}{ Variabel } & \multicolumn{2}{c}{ Levene's Test } & \multicolumn{2}{c}{ t test } \\
\cline { 3 - 6 } & Equal & & sig. & t & sig. \\
\hline \multirow{4}{*}{$\begin{array}{c}\text { Kepuasan } \\
\text { Kerja }\end{array}$} & Variaces & & & & \\
& Assumed & & & & \\
& Equal & 0.273 & 0.603 & 40.081 & 0.000 \\
& Variaces & & & & \\
& Assumed & & & & \\
\hline
\end{tabular}

Berdasarkan hasil dari Levene's Test pada Tabel 22 variabel kepuasan kerja yang dilihat dari niliai F-hitung untuk asumsi varians adalah 0.273 dengan angka (Sig.) 0,603 > 0,05, yang berarti varians populasi dari kedua kelompok memiliki persamaan atau homogen. Kemudian hasil dari t-hitung variabel kepuasan kerja adalah 40.081 dengan angka (Sig.) 0,000. Berdasarkan hasil angka (Sig.) 0,000<0,05 maka H0 ditolak. Artinya terdapat perbedaan kepuasan kerja antara pegawai tetap dengan pegawai outsourcing.

Tabel 23

Levene's Test dan t Test Komitmen Organisasi

\begin{tabular}{|c|c|c|c|c|c|}
\hline \multirow{2}{*}{\multicolumn{2}{|c|}{ Variabel }} & \multicolumn{2}{|c|}{ Levene's Test } & \multicolumn{2}{|c|}{ t test } \\
\hline & & $\mathbf{F}$ & sig. & t & sig. \\
\hline $\begin{array}{l}\text { Komitmen } \\
\text { Organisasi }\end{array}$ & $\begin{array}{l}\text { Equal } \\
\text { Variaces } \\
\text { Assumed }\end{array}$ & 10.158 & 0.002 & 32.945 & 0.000 \\
\hline
\end{tabular}

Berdasarkan hasil dari Levene's Test pada Tabel 23 variabel komitmen organisasi yang dilihat dari niliai F-hitung untuk asumsi varians adalah 10.158 dengan angka (Sig.) 0,002 > 0,05, yang berarti varians populasi dari kedua kelompok memiliki perbedaan. Kemudian hasil dari t-hitung variabel komitmen organisasional adalah 32.945 dengan angka (Sig.) 0,000. Berdasarkan hasil angka (Sig.) $0,000<0,05$ maka H0 ditolak. Artinya terdapat perbedaan komitmen organisasi antara pegawai tetap dengan pegawai outsourcing

\section{Implikasi Manajerial}

Implikasi manajerial bertujuan sebagai rekomendasi manajerial yang dapat diterapkan oleh perusahaan pengguna maupun penyedia layanan jasa outsourcing. Pada bagian ini akan dijabarkan mengenai hal-hal yang dapat dijadikan referensi bagi manajemen Universitas Widyatama sebagai perusahaan objek penelitian dalam menjalankan bisnisnya berdasarkan hasil dan analisis penelitian. Berdasarkan hasil analisis statistik deskriptif sebagian besar pegawai tetap memiliki masa kerja yang relatif lama yaitu 16 - 20 tahun, sedang pegawai outsourcing memiliki masa kerja berkisar 1-5 tahun. Hal ini menunjukkan bahwa pegawai outsourcing di perusahaan terbilang cukup baru.

Dilihat dari rentang usia, mayoritas pegawai tetap berusia antara 46 - 50 tahun, sedangkan pegawai outsourcing berusia 20 -25 tahun. Dapat dikatakan bahwa pegawai outsourcing dengan rentang usia tersebut masih senang mencari tempat kerja baru dengan harapan mendapatkan pekerjaan yang lebih baik. Oleh sebab itu, ada dua hal yang harus dipertimbangkan oleh perusahaan, pertama untuk pegawai tetap sudah mendekati masa pensiun dan untuk pegawai outsourcing kemungkinan untuk pegawai keluar dari perusahaan tinggi. Sehingga perusahaan harus mempersiapkan strategi dalam hal pengembangan karir untuk para 
pegawainya agar pegawai memiliki komitmen yang tinggi untuk tetap bekerja di perusahaan untuk pegawai outsourcing dan strategi untuk pegawai tetap yang sebagian besar sudah hampir mendekati masa pensiun.

Jika dilihat dari hasil analisis t-test, menunjukkan bahwa dari tiga variabel yakni pemberdayaan, kepuasan kerja, dan komitmen organisasi, untuk pegawai outsourcing memiliki nilai yang lebih tinggi dilihat dari variabel pemberdayaan dan kepuasan kerja, sedangkan untuk komitmen organisasi pegawai tetap memiliki nilai yang lebih tinggi, hal ini bisa diakibatkan karena sebagian besar pegawai tetap memiliki masa kerja lebih lama, sehingga rasa memiliki sudah melekat pada diri mereka (pegawai tetap).

Komitmen organisasi yang rendah pada pegawai outsourcing memberikan dampak buruk kepada perusahaan pengguna jasa outsourcing, oleh sebab itu perusahaan diharapkan dapat memberikan motivasi, tunjangan yang sesuai dan strategi lainnya agar komitmen organisasi dari pegawai outsourcing meningkat. Sehingga, ketika pegawai outsourcing bekerja pada perusahaan penerima layanan outsourcing, mereka melakukan pekerjaan dengan senang hati tanpa ada perasaan dikesampingkan oleh perusahaan.

\section{Kesimpulan}

Berdasarkan analisis yang telah dilakukan dapat disimpulkan sebagai berikut:

1. Adanya perbedaan Pemberdayaan antara pegawai tetap dan pegawai outsourcing, dimana nilai rata-rata variabel pemberdayaan pegawai outsourcing lebih tinggi dibandingkan dengan pegawai tetap.
2. Adanya perbedaan Kepuasan Kerja antara pegawai tetap dan pegawai outsourcing, dimana nilai rata-rata variabel Kepuasan Kerja pegawai outsourcing lebih tinggi dibandingkan dengan pegawai tetap.

3. Adanya perbedaan Komitmen Organisasi antara pegawai tetap dan pegawai outsourcing, dimana nilai ratarata variabel Komitmen Organisasi pegawai tetap lebih tinggi dibandingkan dengan pegawai outsourcing. Terdapat perbedaan varians antara kelompok pegawai tetap dan pegawai outsourcing pada variabel Komitmen Organisasi.

\section{Saran-saran}

Berdasarkan dari hasil analisis data dan kesimpulan yang diperoleh dalam penelitian ini, penulis dapat memberikan saran yang mungkin dapat dipergunakan sebagai bahan pertimbangan oleh universitas dalam menentukan kebijakan universitas. Adapun saran yang ingin penulis sampaikan berdasarkan tanggapan responden dan analisis penelitian adalah sebagai berikut:

1. Agar kegiatan operasional berjalan dengan lancar, sebaiknya manajemen Universitas Widyatama dapat meningkatkan variabel Pemberdayaan pegawai tetap dengan meningkatkan komunikasi antara pegawai tetap bagian kebersihan dengan atasannya sehingga terjalin hubungan yang baik, yang akhirnya dapat meningkatkan variabel Pemberdayaan pegawai tetap.

2. Agar kegiatan operasional berjalan dengan lancar, sebaiknya manajemen Universitas Widyatama dapat meningkatkan variabel Kepuasan Kerja pegawai tetap dengan memperbaiki 
pendapat sangat tidak setuju pegawai tetap terutama dalam hal tunjangan yang diberikan, mendapatkan penghargaan/pengakuan ketika melakukan pekerjaan lebih baik, dan menghargai apa yang sudah dilakukan oleh pegawai tetap bagian kebersihan.

3. Untuk penelitian selanjutnya diharapkan dapat menambah variabel dan indikator untuk lebih mengetahui lebih mendalam perbandingan persepsi antara pegawai tetap dan pegawai outsourcing

\section{DAFTAR PUSTAKA}

Devi, Ni Made Bella Sintya, Noer, Bustanul Arifin, \& Rahmawati, Yani. (2017). Analisis Perbandingan Pegawai Tetap dan Pegawai Outsourcing Ditinjau dari Pemberdayaan, Kepuasan Kerja, dan Komitmen Organisasional. Jurnal Sains Dan Seni ITS, 6(2), D276D280.

Fadzilah, Ari. (2006). Analisis Pengaruh Pemberdayaan Karyawan dan Self Of Efficacy Terhadap Kinerja Karyawan Bagian Penjualan (Studi Kasus Pada PT. Sinar Sosro Wilayah Pemasaran Semarang). Jurnal Studi Manajemen Organisasi, 3(1), 12-27.

Faisal, Gatot S. M. (2009). How to be A Smarter Taxpayer: Bagaimana menjadi Wajib Pajak. Grasindo.

Gary, Dessler. (2009). Manajemen Sumber Daya Manusia. Jakarta: Edisi Kesepuluh Jilid Dua PT Indeks Halaman, 46.

Herawati, Rina. (2010). Kontrak dan outsourcing: harus makin diwaspadai. AKATIGA.
Leovani, Ega. (2016). Implementasi Model Pemberdayaan Karyawan (Employee Empowerment) Di Pt Fifgroup Tbk Cabang Palembang. Jurnal Manajemen, 20(2), 245-261.

Nugroho, Bhuono Agung. (2005). Strategi jitu memilih metode statistik penelitian dengan SPSS. Yogyakarta: Andi.

Nurandini, Arina, \& Lataruva, Eisha. (2014). Analisis pengaruh komitmen organisasi terhadap kinerja karyawan (studi pada pegawai perum PERUMNAS Jakarta). Fakultas Ekonomika dan Bisnis.

Sugiyono, P. D. (2012). Metode Penelitian Kuantitatif Kualitatif Dan R\&D (Vol. 8). Alfabeta. Bandung.

Syahrani, Riduan. (2008). Hukum Acara Perdata di Lingkungan Peradilan Umum, cet. IV Jakarta: Pustaka Kartini.

Zainal, Veithzal Rivai, Ramly, $\mathrm{H}$. Mansyur, Mutis, Thoby, \& Arafah, Willy. (2019). Manajemen sumber daya manusia untuk perusahaan dari teori ke praktik. 